\title{
CHEMICAL VARIATION OF SPILANTHES SPECIES (ASTERACEAE) A MEDICINAL HERB IN PENINSULAR INDIA - REVEALED BY GCMS-MS
}

\author{
1 \& 2 Lavanya Devi K., ${ }^{2}$ M.B. Shivanna and ${ }^{1}$ S. Ganeshan \\ ${ }^{1}$ Division of Plant Genetic Resources, Indian Institute of Horticultural Research, Bangalore, \\ Karnataka, India-560089 \\ ${ }^{2}$ Department of Applied Botany, Kuvempu University, Shankaraghatta, Shimoga, Karnataka, India-577451
}

\begin{abstract}
Spilanthes (Family: Asteraceae, tribe: Heliantheae), commonly known as 'tooth-ache' plant, is used in traditional medicine for curing several diseases across the world and species are reported to be distributed in peninsular India. The study on the comparison of the chemical constituents among Spilanthes species is lacking. A systematic study of chemical compounds could contribute to the knowledge of bioactive compounds but systematics of the genus as well. In this context, species of Spilanthes in peninsular India were selected for carrying out a detailed study of their chemical composition and their significance in chemotaxonomy. The chemical compounds of Spilanthes species in peninsular India were investigated by GCMS-MS. A total of 81 compounds were identified from leaf, inflorescence and root of S. calva, S. ciliata, S. oleracea, S. paniculata, S. radicans and S. uliginosa. The hydrocarbons (28\%) formed the major constituent, followed by terpenoids (15\%), esters (9\%), sterols (8\%), aldehydes \& ketones (7\%), alcohols (3\%) and the main bioactive principle alkamide (5\%), and rest of compounds forming $25 \%$ of total constituent. The chemotaxonomic significance of these compounds in each species was discussed. The phylogeny was constructed and principal coordinate analysis was carried out to study the relationship among species. The present study documented the chemical variation among the six Spilanthes species and some were species specific. The quantification of compounds in leaf, inflorescence and root of six species could contribute to the systematics and application in modern medicines. The phylogeny revealed the distance among the plant parts and the species under study where S. ciliata and S. paniculata were closely related, to this cluster S. oleracea was grouped, then S. uliginosa followed by S. radicans. To this main cluster S. calva was grouped indicating the far distance of this native species with other species including another native species S. paniculata.
\end{abstract}

\section{KEY WORDS}

Spilanthes, GCMS-MS, alkamides, terpenoids, sterols, esters, phylogeny, principal coordinate analysis.

\section{INTRODUCTION}

Spilanthes, of Asteraceae, is distributed in the warmer regions of both hemispheres and are used in traditional medicine by different civilizations in the world for tooth-ache, gastritis, gastric ulcers, mucous membrane inflammation, burns and wounds and as local anaesthetic (Christophe, 2006; Prachayasittikul et al. 2009; Chakraborty et al. 2011). The bioactive compounds like alkamides, terpenoids, esters and other compounds exhibit various biological activities like radical scavenging, diuretic (Rajesh et al. 2011), immunomodulatory (Savadi et al. 2010), antipyretic (Trease and Evans 1972; Rajnarayana et al. 2001), antimicrobial (Nakatani, 1992; Krishnaswamy et al. 1975), larvicidal (Pandey and Agarwal, 2009), molluscicidal (Timothy et al. 1982) and insecticidal activities (Jondiko et al. 1986). Although morphological parameters find importance in the identification of species of Spilanthes, there existed certain difficulties in the distinct separation of species 
with rayed and discoid florets (S. paniculata rayed in India; discoid in other countries (Saldanha and Nicolson, 1976; Jansen, 1981) and its misidentification as Acmella species (Jansen, 1981; Chung, 2007). Under these circumstances, chemotaxonomic characterization could be used for differentiation of these plant taxa. Evidences in respect of chemical finger prints have been quite useful in species characterization in plants (Joelma et al. 2011). The basic categories used by folk taxonomists for classification include edibility, taste, colour, smell and medicinal values that are fundamentally based on chemical properties (Jones and Luchsinger, 1986). The analytical techniques such as chromatography find application in distinguishing species based on chemical compounds.

Asteraceae, a phylogenetically young family, is known for secondary metabolites and distinct primary metabolites (Herout, 1971). The variation in chemical compounds could yield confirmative results based on which species could be classified with the support of distinct morphological characteristics. Since Spilanthes is medicinally important, previous studies documented the presence of chemical compounds (Table 1) and their relation to disease therapy.

Table 1: Chemical constituents documented in species of Spilanthes in previous studies

\begin{tabular}{|c|c|c|c|}
\hline S.N. & Chemical compounds & Species & Reference \\
\hline 1. & $\begin{array}{l}\text { Sesquiterpenes, } \beta \text { bisalobenes, } \beta \text { caryophyllene, } \\
\alpha \text { - caryophyllene and cadinene }\end{array}$ & S. americana & Baruah and Pathak 1999 \\
\hline 2. & Sesquiterpenes, bisalobenes, caryophyllene, cadinene & S. americana & Anon. 2013 \\
\hline 3. & $\begin{array}{l}\text { Caryophyllene, limonene, myrcene, sabinene, cis- } \\
\text { ocimene, } \\
\beta \text { - pinene }\end{array}$ & S. calva & Begum et al. 2008 \\
\hline 4. & Caryophyllene & S. ciliata & Anon. 2013 \\
\hline 5. & $\begin{array}{l}\text { Spilanthol (N- isobutyl 2E,4Z, 8Z, 10E- } \\
\text { dodecatetraenamide) }\end{array}$ & S. filicaulis & Wahab et al 2013 \\
\hline 6. & $\begin{array}{l}\text { Spilanthol (N- isobutyl 2E,4Z, 8Z, 10E- } \\
\text { dodecatetraenamide) }\end{array}$ & S. acmella & $\begin{array}{l}\text { Ramsewak et al. 1999; } \\
\text { Bae et al. 2010; Boonen et al. } \\
\text { 2008; Stacy et al. } 2010\end{array}$ \\
\hline 7. & $\begin{array}{l}\text { Spilanthol (N- isobutyl 2E,4Z, 8Z, 10E- } \\
\text { dodecatetraenamide) }\end{array}$ & S. alba & Standley and Calderon 1944 \\
\hline 8. & $\begin{array}{l}\text { Spilanthol (N- isobutyl 2E,4Z, 8Z, 10E- } \\
\text { dodecatetraenamide) }\end{array}$ & S. mauritiana & Jondiko et al.1986 \\
\hline 9. & $\begin{array}{l}\text { Spilanthol (N- isobutyl 2E,4Z, 8Z, 10E- } \\
\text { dodecatetraenamide) }\end{array}$ & S. oleracea & $\begin{array}{l}\text { Nakatani and Nagasimha } \\
1992\end{array}$ \\
\hline 10. & $\begin{array}{l}\text { Spilanthol (N- isobutyl 2E,4Z, 8Z, 10E- } \\
\text { dodecatetraenamide) }\end{array}$ & S. radicans & Ramirez et al. 2011 \\
\hline 11. & $\begin{array}{l}\text { Spilanthol (N- isobutyl 2E,4Z, 8Z, 10E- } \\
\text { dodecatetraenamide) }\end{array}$ & S. calva & Baruah and Pathak 1999 \\
\hline 12. & $\mathrm{~N}$ (methylbutyl ) undeca $(2 \mathrm{E}, 4 \mathrm{Z}$ ) diene 8,10 diyamide- & S. acmella & $\begin{array}{l}\text { Nakatani and Nagasimha, } \\
1992\end{array}$ \\
\hline 13. & $\mathrm{~N}$ isobutyl $2 \mathrm{E}, 6 \mathrm{Z} 8 \mathrm{E}$ decatrienamide & S. filicaulis & Wahab et al. 2013 \\
\hline 14. & $\mathrm{~N}$ isobutyl $2 \mathrm{E}, 6 \mathrm{Z} 8 \mathrm{E}$ decatrienamide & S. americana & Anon. 2013 \\
\hline 15. & N-Isobutyl-(6Z,8E)-decadienamide & S. calva & Baruah and Pathak, 1999 \\
\hline 16. & $\mathrm{~N}$-(2-Phenylethyl)(2Z,4E)-octadienamide & S. radicans & Ramirez et al.2011 \\
\hline 17. & (2E)-N-(3-Ethynylphenyl)-3-phenyl-2-propenamide & S. radicans & Charvez et al. 2003 \\
\hline 18. & Sitosterol-O-D-glucoside & S. acmella & Ramsewak et al. 1999 \\
\hline
\end{tabular}




\begin{tabular}{llll}
\hline 19. & Lupenyl acetate & S. ocymifolia & Castillo et al. 1984 \\
20. & Stigma sterol and sitosterol & S. acmella & Pandey et al. 2007 \\
21. & Stigma sterol and its glycoside & S. acmella & Supaluk et al. 2009 \\
22. & Docosanoic acid & S. oleracea & Phrutivorapongkul, 2008 \\
23. & Lauric acid, myristic acid, palmitic acid, linoleic acid, & S. acmella & Krishnaswamy et al. 1975 \\
24. & n- Hexadecanoic acid and Myristic acid & S. acmella & Leng et al. 2011 \\
25. & n- Hexadecanoic acid and Tetradecanoic acid & S. acmella & Vibha et al. 2011 \\
\hline
\end{tabular}

Against this background, in the present study, six species of Spilanthes - S. calva, S. ciliata, S. oleracea, S. paniculata, S. radicans and S. uliginosa occurring in peninsular India were studied for their chemical compounds, which could be used as a taxonomic criteria for their characterization. The GCMS-MS, a powerful analytical method, was employed to detect compounds in complex matrices and at trace levels in Spilanthes species.

\section{MATERIALS AND METHODS}

Selection of plant material: In the present study, six Spilanthes species viz., S. calva, S. ciliata, S. oleracea, S. paniculata, S. radicans and S. uliginosa growing in different regions of peninsular India were identified based on morphological characteristics with the help of descriptors detailed in flora (Manilal and Sivarajan, 1982; Saldanha and Nicolson, 1976; Pullaiah, 1997). The specimens of the above plant species were collected and grown in the shade net house and field gene bank of the Division of Plant Genetic Resources, Indian Institute of Horticultural Research, Bengaluru. The herbaria and seeds of the voucher specimens were deposited in the Division of Plant Genetic Resources, Indian Institute of Horticultural Research, Bengaluru.

\section{Preparation of plant materials and extraction}

The plant materials viz. leaf, inflorescence and root were collected at full blooming stage of 2-3 monthsold-plant and washed in running tap water and airdried at ambient room temperature $\left(25^{\circ} \mathrm{C} \pm 2^{\circ} \mathrm{C}\right)$ until a constant weight was obtained. The plant material $(2$ g) was macerated using mortar and pestle, soaked in $90 \%$ methanol $(20 \mathrm{ml})$ and the homogenate was allowed to stand for three days; this was repeated for three times where methanol was added every third day. The combined supernatant $(60 \mathrm{ml})$ was concentrated to $10 \mathrm{ml}$ below $40^{\circ} \mathrm{C}$ by using rotary flash evaporator (Germany) and the concentrate was dissolved in distilled $\mathrm{H}_{2} \mathrm{O}(10 \mathrm{ml})$. The solution was extracted with $20 \mathrm{ml}$ of $\mathrm{n}$-hexane (SRL, Bangalore) three times in a separating funnel. The bottom layer of hexane extract was collected and concentrated to dryness at $40^{\circ} \mathrm{C}$ in a rotary evaporator coupled to a water pump. The dried extract was eluted with $1 \mathrm{ml}$ of n-hexane: diethyl ether (1:1) and used for GCMS analysis.

\section{Gas chromatography tandem mass spectrometry GCMS-MS analysis}

The GCMS-MS analysis was carried out using Varian 4000 Ion trap GCMS-MS (Varian, USA) with Fused silica column (column-30 m $\times 0.25 \mathrm{~mm}$ ID with $0.25 \mathrm{~m}$ film thickness). The instrument was set to an initial temperature of $110 \circ \mathrm{C}$, and maintained at the same temperature for $2 \mathrm{~min}$. At the end of this period, the oven temperature was up to 280 C (at the rate of an

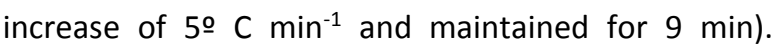
Injection port temperature was ensured at 250 ㅇ $\mathrm{C}$ and Helium flow rate at $1 \mathrm{ml} \mathrm{min}^{-1}$; the ionization voltage was $70 \mathrm{eV}$. Samples were injected in split less mode. The column was directly coupled to a trace MS (mass spectrometry). The mass spectral scan range was set at $45-450\left(\mathrm{mz}^{-1}\right)$. The mass spectra and reconstructed chromatograms were obtained by automatic scanning in the mass range of $z^{-1} 35-250$ at $4.4 \mathrm{scan} \mathrm{sec}^{-1}$. Chromatographic peaks were checked for homogeneity with the aid of mass chromatogram for characteristic fragment ions.

Identification and quantification of chemical compounds

The identification of chemical compounds was based on comparison of their GC mass spectra and retention 
times with those of authentic standards (SigmaAldrich, India). The tentative identification of compounds was carried out by comparison of their mass spectra with spectral data from the National Institute Standard and Technology (NIST) and Willey G 1035 A library having more than 62,000 patterns. The spectrum of unknown components was compared with the spectrum of known components stored in the NIST library. The name, molecular weight and structure of components of test materials were ascertained. The confirmation was also supported with reference to previous records in the literature. For quantification purposes, calibration curves were used wherever standards were available; otherwise semi quantitative analyses were performed. The chemical compound content was calculated from GC peak areas and calculating the percentage by total peak area of the profiling.

Cluster analysis: Compounds were scored for cluster analysis based on the presence (1) and absence (0) data and a dendrogram was obtained by Parsimony method using the software PAUP version 4.0. The inter-specific relationships and the distance among plant parts based on the chemical compounds present were also obtained and discussed.

\section{RESULTS AND DISCUSSION}

The chemical constituents were identified by comparing their mass spectra with those available in NIST library and calculated linear retention indices (RI) were calculated and compared with values in the literature. More than 100 compounds were identified by GCMS-MS analysis. Compounds with significant quantity (81 compounds) were identified and separated into seven major groups based on their chemical structures. Hydrocarbons (28\%) were the major constituents, followed by terpenoids (15\%), esters (9\%), sterols (8\%), aldehydes and ketones (7\%), the main bioactive principle alkamides (5\%), alcohols (3\%), and other compounds forming 25\% (Figure 1). Among these, compounds with chemotaxonomic significance were studied in detail. The chemical compounds occurring in different plant parts are detailed in Table 2.

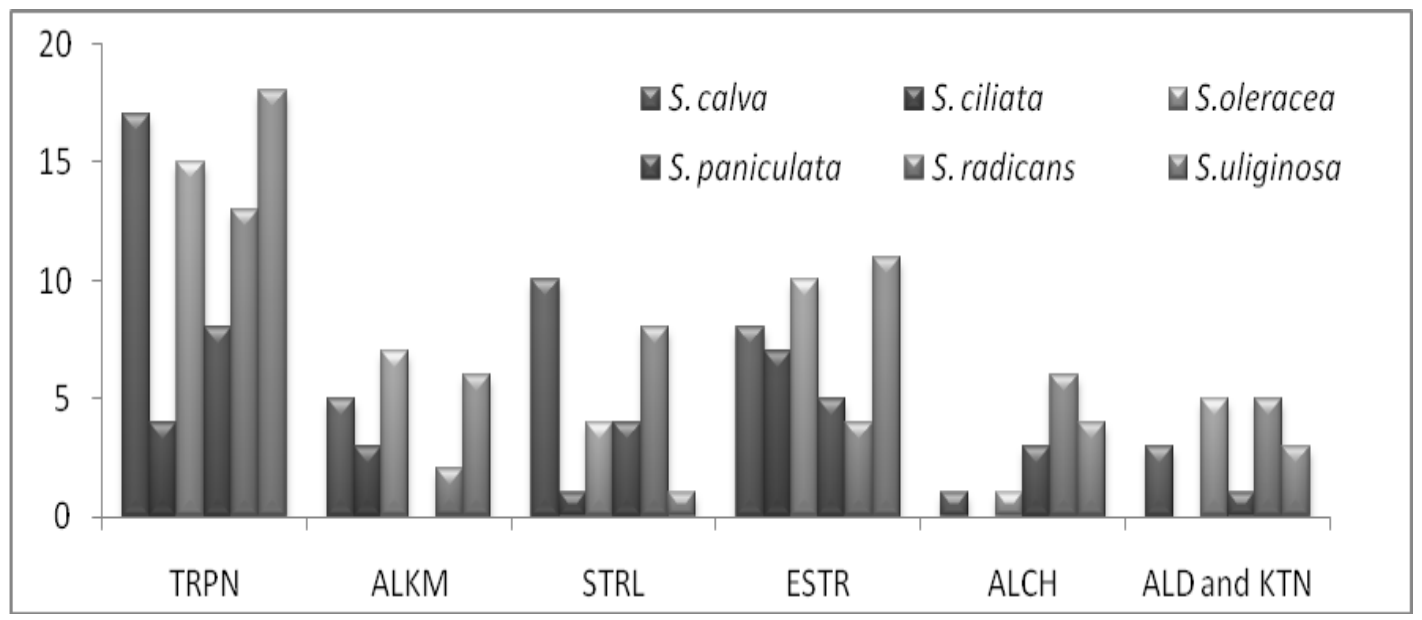

Figure 1: The chemical constituent occurring in S. calva, S. ciliata, S. oleracea, S. paniculata, S. radicans and S. uliginosa by GCMS analysis. TRPN-Terpenoids; ALKM-Alkamides; STRL-sterols; ESTR-esters; ALCH-alcohols; ALD and KTN-aldehydes and ketones. 
Table 2: The chemical constituents (quantitave, \%) occurring in different parts of Spilanthes species viz., S. calva, S. ciliata, S. oleracea, S. paniculata, S. radicans and S. uliginosa by GCMS-MS analysis.

\begin{tabular}{|c|c|c|c|c|c|c|c|c|c|c|c|c|c|c|c|c|c|c|}
\hline \multirow{2}{*}{$\begin{array}{l}\text { Species/ } \\
\text { plant } \\
\text { parts }\end{array}$} & \multicolumn{3}{|c|}{ Alkamides } & \multicolumn{3}{|c|}{ Terpenoids } & \multicolumn{3}{|c|}{ Sterols } & \multicolumn{3}{|c|}{ Esters } & \multicolumn{3}{|c|}{ Alcohols } & \multicolumn{3}{|c|}{ Hydrocarbons } \\
\hline & $\mathbf{L}$ & I & $\mathbf{R}$ & $\mathbf{L}$ & I & $\mathbf{R}$ & $\mathbf{L}$ & I & $\mathbf{R}$ & $\mathbf{L}$ & I & $\mathbf{R}$ & $\mathbf{L}$ & I & $\mathbf{R}$ & $\mathbf{L}$ & I & $\mathbf{R}$ \\
\hline SC & 1.9 & 4.9 & 7.5 & 3.6 & 2.1 & 0.1 & 21.6 & 25.4 & 33.6 & 22.3 & 26.8 & 6.3 & 4.1 & 9.2 & 53.9 & 41 & 19 & 4.2 \\
\hline $\mathrm{SCl}$ & 0.4 & 0.3 & 0.6 & $7 . .3$ & 37.3 & 8.3 & 7.6 & 3.8 & 2.2 & 35.8 & 15.3 & 43.2 & 1.3 & 7.1 & 1.7 & 32.2 & 21.5 & 18.8 \\
\hline so & 9.2 & 18 & 1.2 & 16.6 & 9.2 & 24.2 & 19.2 & 17.1 & 22.6 & 26.3 & 9.6 & 15.7 & 5.9 & 1.3 & 0.2 & 3.6 & 12.6 & 2.5 \\
\hline SP & - & - & - & 6.5 & 23.8 & 46.5 & 0.6 & 17.8 & 4.5 & 7.0 & 7.7 & 5.4 & 23.6 & 9.1 & 3.5 & 5.3 & 18.2 & 29.3 \\
\hline SR & 1.5 & 0 & 0 & 15.9 & 31.8 & 6.6 & 18.9 & 14.4 & 25.5 & 1.9 & 1.1 & 0.8 & 18.7 & 7.7 & 30.2 & 15.0 & 17.8 & 6.4 \\
\hline SU & 2.8 & 1.4 & 7.6 & 18.8 & 24 & 10.3 & 0.05 & 0.02 & 0 & 34.0 & 59.1 & 47.5 & 2.4 & 1.3 & 1.7 & 16.1 & 15.1 & 8.1 \\
\hline
\end{tabular}

L=Leaf, I=Inflorescence and R=Root.

In GCMS-MS profiling, a total of 19 terpenoids were identified, with maximum (18) in S. uliginosa and minimum (4) in S. ciliata. Three terpenoids copaene, caryophyllene and longifolin were present in all six species. The terpenoid cadinene was present in all species except S. ciliata and S. oleracea while elemene in all except $S$. calva and $S$. oleracea. Totally 11 alkamides, S. calva-3, S. ciliata-3, S. oleracea-7, S. radicans- 2 and $\mathrm{S}$. uliginosa- 6 were identified and in S. paniculata no alkamides were documented. Among these, N-isobutyl 2E, 4Z, 8Z, 10E dodecatetraenamide, the main bioactive principle known as spilanthol was recorded in four species namely S. calva, S. ciliata, S. oleracea and S. uliginosa. Out of 19 sterols reported, maximum (10) was in S. calva and minimum in $S$. ciliata and S. uliginosa contained a single sterol, where as $\mathrm{S}$. radicans contained there were 8 sterols. There were 4 sterols in S. oleracea and S. paniculata. Among these, sitosterol was present in all except in S. ciliata and S. uliginosa; stigmasta-5,22-dien-3-ol acetate (3á,22Z) was present in all except S. ciliata and S. oleracea; á-sitosterol acetate was recorded in S. calva, S. ciliata, S. paniculata and S. radicans. Nineteen esters were identified, maximum esters (11) were recorded in S. uliginosa and minimum (4) in S. radicans; in others, S. ciliata-7, S. oleracea-10 and $\mathrm{S}$. paniculata-5. Among esters, the common ester dodecanoic acid was present in all six species; octadecanoic acid was present in all except S. calva and 9,17-Octadecadienal, (Z) was present in all except S. ciliata. Totally seven alcohols were recorded from Spilanthes species. In the present study, few chemical compounds were species-specific, and few others common to all six species and still others common to two or three species. In addition to the presence of above compounds, all species of Spilanthes were positive for Vitamin $E$ in inflorescence and leaf and in S. uliginosa in roots, as well, where it was present in high quantity.

The chemical profiling helped in the identification of few compounds which were species-specific (Table 3) and were restricted to two or three species. For example, S. calva could be identified by the presence of valencene and amorphene, while $S$. ciliata could be identified by the presence of 3-carene and cubebene. Spilanthes radicans could be identified by the presence of (+)-Aristol-9-ene, á-lonone, N-(2Phenylethyl)(2Z,4E)-octadienamide and (2E)-N-(3- 
Ethynylphenyl)-3-phenyl-2-propenamide. However the presence of 7 and 6 compounds were necessary for the identification of S. oleracea and S. uliginosa, where as in case of S. paniculata specific chemicals were not present as such but the chemical compounds common to two or three species were present which could be differentiated further based on the quantity and localization of chemical compounds in different regions of the plant.

Table 3: Spilanthes species-specific chemical compounds and their characteristics

\begin{tabular}{|c|c|c|c|c|c|c|c|c|c|c|c|}
\hline \multirow{2}{*}{ RT } & \multirow{2}{*}{ Chemical Compounds } & \multirow{2}{*}{\multicolumn{2}{|c|}{ Group }} & \multirow{2}{*}{\multicolumn{2}{|c|}{$\begin{array}{l}\text { Mol } \\
\text { wt. }\end{array}$}} & \multirow{2}{*}{\multicolumn{2}{|c|}{$\begin{array}{l}\text { Mol. } \\
\text { formula }\end{array}$}} & \multirow{2}{*}{ Species } & \multicolumn{3}{|c|}{ Percentage } \\
\hline & & & & & & & & & $\mathbf{L}$ & I & $\mathbf{R}$ \\
\hline 30.435 & Valencene & \multicolumn{2}{|c|}{ Terpenoid } & \multicolumn{2}{|c|}{204.35} & \multicolumn{2}{|c|}{$\mathrm{C}_{15} \mathrm{H}_{24}$} & S. calva & $*$ & 0.0274 & $*$ \\
\hline 28.523 & à-Amorphene & \multicolumn{2}{|c|}{ Terpenoid } & \multicolumn{2}{|c|}{204.35} & \multicolumn{2}{|c|}{$\mathrm{C}_{15} \mathrm{H}_{24}$} & S. calva & 0.0110 & 0.0687 & $*$ \\
\hline 11.324 & 3-Carene & \multicolumn{2}{|c|}{ Terpenoid } & \multicolumn{2}{|c|}{136.23} & \multicolumn{2}{|c|}{$\mathrm{C}_{10} \mathrm{H}_{16}$} & S. ciliata & $*$ & $*$ & 0.5054 \\
\hline 29.623 & á-Cubenene & \multicolumn{2}{|c|}{ Terpenoid } & \multicolumn{2}{|c|}{204.35} & \multicolumn{2}{|c|}{$\mathrm{C}_{15} \mathrm{H}_{24}$} & S. ciliata & 3.2968 & 15.533 & 2.9094 \\
\hline 27.748 & Trans-Caryophyllene & \multicolumn{2}{|c|}{ Terpenoid } & \multicolumn{2}{|c|}{204.35} & \multicolumn{2}{|c|}{$\mathrm{C}_{15} \mathrm{H}_{24}$} & S. oleracea & 6.8381 & 5.1053 & 0.2348 \\
\hline 28.883 & $\alpha$-humulene & \multicolumn{2}{|c|}{ Terpenoid } & \multicolumn{2}{|c|}{204.35} & \multicolumn{2}{|c|}{$\mathrm{C}_{15} \mathrm{H}_{24}$} & S. oleracea & 0.4269 & 0.4846 & 0.0277 \\
\hline 30.129 & à-Muurolene & \multicolumn{2}{|c|}{ Terpenoid } & \multicolumn{2}{|c|}{204.35} & \multicolumn{2}{|c|}{$\mathrm{C}_{15} \mathrm{H}_{24}$} & S. oleracea & 0.1311 & 0.1704 & 0.0202 \\
\hline 39.714 & $\begin{array}{l}\mathrm{N} \text {-Isobutyl-(6Z,8E)- } \\
\text { decadienamide }\end{array}$ & \multicolumn{2}{|c|}{ Alkamide } & \multicolumn{2}{|c|}{223.35} & \multicolumn{2}{|c|}{$\mathrm{C}_{14} \mathrm{H}_{25} \mathrm{NO}$} & S. oleracea & 0.0424 & 0.6839 & 0.0393 \\
\hline 52.986 & $\begin{array}{l}\text { NN ( } 2 \text { phenyl ethyl 2E } \\
6 Z 8 E \text { decatrienamide) }\end{array}$ & \multicolumn{4}{|c|}{ Alkamide } & & & S. oleracea & 0.4071 & 2.6949 & 0.0220 \\
\hline 35.074 & $\begin{array}{l}(6 \mathrm{E}, 10 \mathrm{Z})-1,6,10- \\
\text { Hexadecatriene }\end{array}$ & Est & & & .39 & & & S. oleracea & 0.0795 & 0.1577 & 0.1209 \\
\hline 48.749 & $\begin{array}{l}1,3,4,10 \\
\text { Nonadecatetraene }\end{array}$ & Est & & & & & & S. oleracea & 0.2618 & 5.4793 & 0.2483 \\
\hline 29.587 & (+)-Aristol-9-ene & Ter & enoid & & .35 & & & S. radicans & $*$ & $*$ & 0.0590 \\
\hline 33.423 & $\begin{array}{l}\text { á-lonone } \\
\mathrm{N}-(2-\end{array}$ & Ter & enoid & & & & & S. radicans & 0.2446 & $*$ & 0.0540 \\
\hline 47.51 & $\begin{array}{l}\text { Phenylethyl)(2Z,4E)- } \\
\text { octadienamide }\end{array}$ & Alk & mide & & & & & S. radicans & 1.1362 & $*$ & $*$ \\
\hline 49.8 & $\begin{array}{l}(2 \mathrm{E})-\mathrm{N}-(3- \\
\text { Ethynylphenyl)-3- } \\
\text { phenyl-2- } \\
\text { propenamide }\end{array}$ & Alk & mide & & .29 & & ${ }_{3} \mathrm{NO}$ & S. radicans & 0.3411 & $*$ & $*$ \\
\hline 50.497 & & $\begin{array}{l}\mathrm{N}(2 \\
8 \mathrm{Z},\end{array}$ & $\begin{array}{l}\text { methy } \\
\text { OE) do }\end{array}$ & & $\begin{array}{l}\text { unde } \\
\text { traen }\end{array}$ & & $4 \mathrm{E}$ & S. uliginosa & $*$ & $*$ & 0.5922 \\
\hline 51.834 & $\begin{array}{l}\mathrm{N}(2 \text { methyl butyl) unde } \\
(2 \mathrm{E}, 4 \mathrm{Z}) \text { diene }\end{array}$ & & Alkam & & 243. & & $\begin{array}{l}\mathrm{C}_{16} \mathrm{H}_{2} \\
{ }_{1} \mathrm{NO}\end{array}$ & S. uliginosa & 0.6246 & 0.9027 & $*$ \\
\hline 42.213 & $\begin{array}{l}\text { E,E, } 10,12 \text { Hexadecadie } \\
\text { ester }\end{array}$ & & Ester & & 238. & & $\begin{array}{l}\mathrm{C}_{16} \mathrm{H}_{3} \\
{ }_{0} \mathrm{O}\end{array}$ & S. uliginosa & $*$ & 0.5547 & $*$ \\
\hline 18.917 & 3-Thujen-2-one & & Terper & & & & & S. uliginosa & $*$ & 0.3096 & $*$ \\
\hline 28.907 & à-Bisabolene & & Terpe & & 204. & & $\begin{array}{l}\mathrm{C}_{15} \mathrm{H}_{2} \\
4\end{array}$ & S. uliginosa & $*$ & $*$ & 0.1005 \\
\hline 30.961 & (+)-á-Funebrene & & Terpe & & 204. & & $\begin{array}{l}\mathrm{C}_{15} \mathrm{H}_{2} \\
4\end{array}$ & S. uliginosa & 2.7082 & $*$ & $*$ \\
\hline
\end{tabular}


RT=Retention time; Mol. formula=Molecular formula; Mol. wt. =Molecular weight; KI=Kovat's index. L=Leaf; I=inflorescence; R=root. *=absent.

Among chemical compounds, alcohols were the main constituent (root-53.9\%) and terpenoids the minor constituent (root- $0.1 \%$ ) in S. calva, while terpenoids were major (Inflorescence- 37.3\%) and alkamides (inflorescence - 0.3\%) minor in S. ciliata. In S. oleracea, esters were major components (leaf- 26.3\%) and alcohol was the minor (root- $0.2 \%$ ). In S. paniculata, terpenoids were major (root-46.5\%) ones and without alkamides. In S. radicans, major compounds were terpenoids (inflorescence- 31.8\%) and minor constituent was ester (root- 1.1 \%). In S. uliginosa, esters formed the major component (inflorescence- 59.1\%) and sterols not documented in roots. Among chemical compounds, ester content was high (59.1\%), followed by alcohols (53.9\%), terpenoids (46.5\%), hydrocarbons (41\%), sterols (33.6\%) and alkamides (18\%) of the total constituents and the other compounds formed about $25 \%$ of the total profile.

The principal coordinate analysis exhibited the grouping of Spilanthes species, irrespective of the chemical composition in plant parts and there was no clear distance among the species (Figure 1). The localization of chemical compounds was found varying in each species

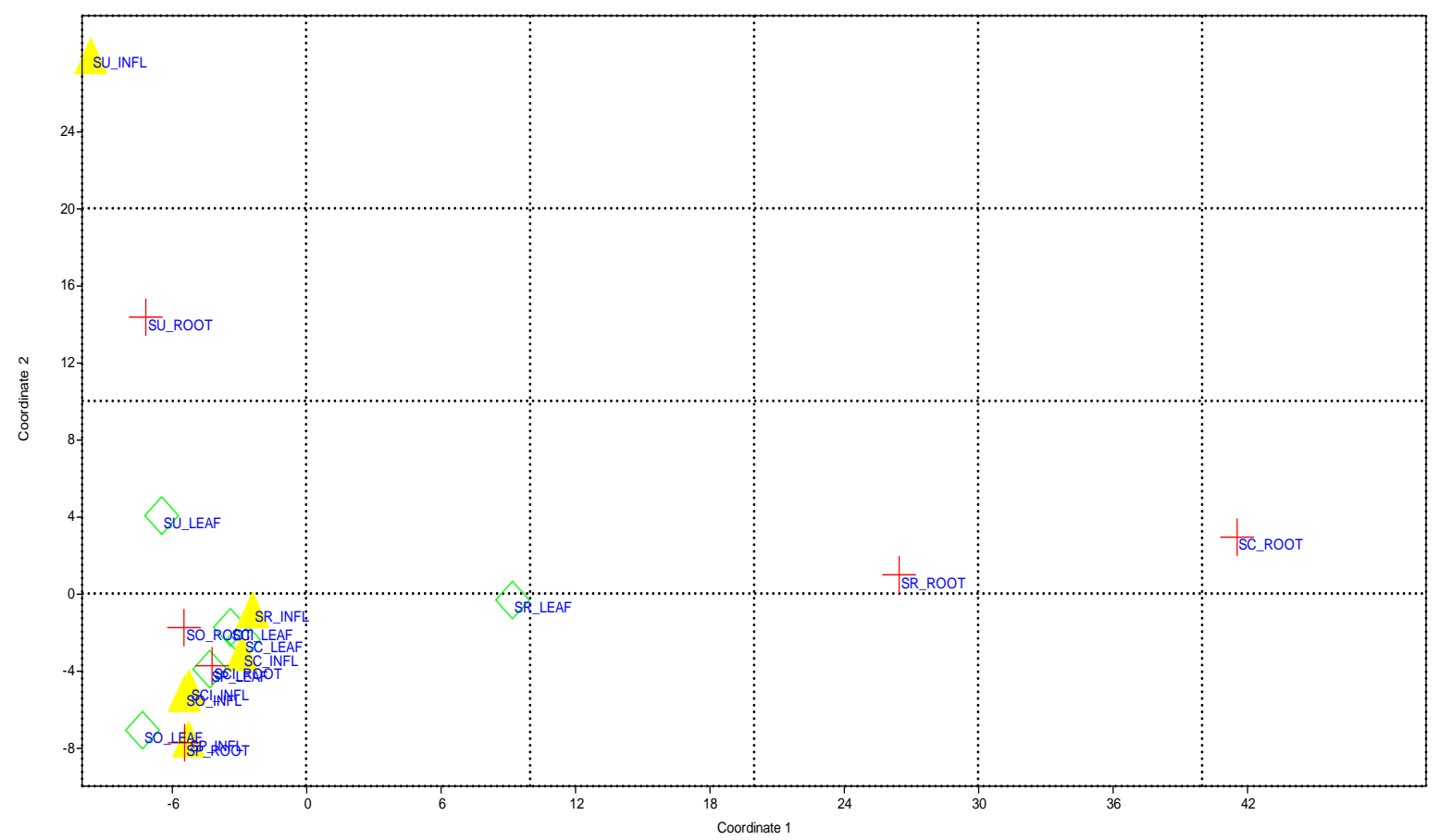

Figure 1: Principal coordinate analysis of chemical components of Spilanthes species (plant parts leaf, inflorescence and root. SC- S. calva, SCI- S. ciliata, SO- S. oleracea, SP- S. paniculata, SR- S. radicans and SU- S. uliginosa)

The cluster analysis constructed based on chemical compounds revealed the relationship of six Spilanthes species. Spilanthes calva was separated from the single cluster formed by five other species at distance of 5 . In the cluster S. ciliata and S. paniculata were closely related to which $\mathrm{S}$. oleracea was grouped. To this S. uliginosa and later S. radicans were grouped (Figure 2). 


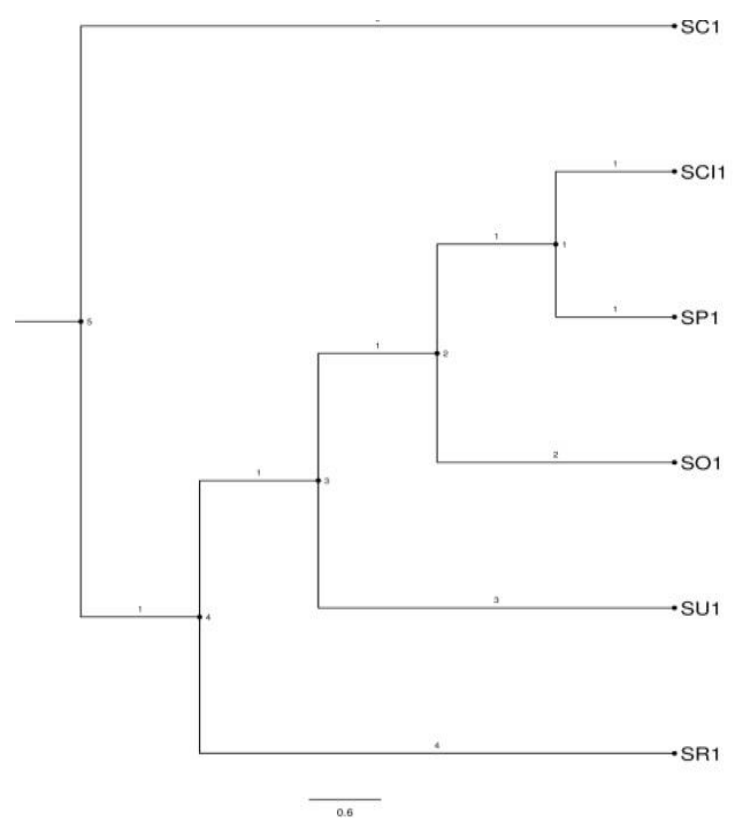

Figure 2: Cluster analysis based on chemical components of Spilanthes species (SC-S. calva, SCI- S. ciliata, SO- S. oleracea, SP- S. paniculata, SR- S. radicans and SU- S. uliginosa)

Following the significance of chemical compounds to medicinal uses of plant parts, a dendrogram was developed to determine the relation of each plant part of six species. The leaves and inflorescence were grouped together of S. calva, S. ciliata and S. radicans, whereas S. oleracea and S. paniculata inflorescence were grouped together to which S. paniculata leaf was joined. But in case of S. uliginosa, inflorescence and roots clustered together to which $\mathrm{S}$. paniculata root grouped later. The roots of S. calva, S. radicans showed primary clustering to which roots of $S$. paniculata and S. uliginosa were clustered. Hence the grouping in the dendrogram revealed the relationship among species as well as the distance of plant part components of different plant species with each other (Figure 4).

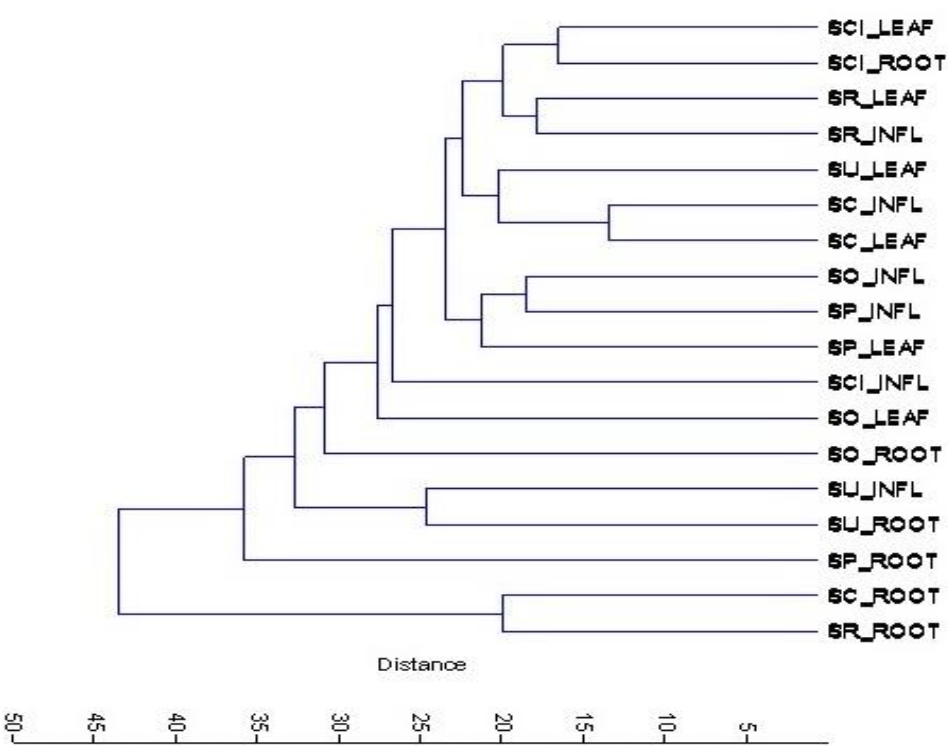

Figure 4: Cluster analysis based on chemical components in leaf, inflorescence and roots of Spilanthes species. (SC- S. calva, SCI- S. ciliata, SO- S. oleracea, SP- S. paniculata, SR- S. radicans and SU- S. uliginosa) 
Preliminary studies in genus Spilanthes revealed the presence of alkaloids, carbohydrates, tannins, steroids, carotenoids, sesquiterpenes, amino acids, glycosides, flavanoids, anthraquinone, saponins and cardiac glycosides (Rajesh et al. 2011 and Shanthi and Amudha, 2010). Some of the above have been determined by GCMS-MS. The Heliantheae tribe for which Spilanthes belongs to, exhibited the presence of acetylenic compounds including sulfur and chloroderivatives, phenyl acetylenes, tetrahydropyrans, alkamides and straight chain acetylenes, sesquiterpenes, lactones and flavonoids (Christensen and Lam, 1991). The present study revealed the presence of alkamides, few lactones, acetylenes, sulfur and chloro- derivates and sesquiterpenes as documented in the above reports. Alkamides present in this genus were characteristic of the tribe Heliantheae, in which both aliphatic and olefinic alkamides were reported (Martin and Becker, 1985). Spilanthes is one of the genera with both alkamides and exhibits the capacity to combine $C_{8}$ to $\mathrm{C}_{18}$ (with exception of $\mathrm{C}_{17}$ ) olefinic and acetylenic acid residues with more widespread $\mathrm{N}$-isobutyl, N-2- methylbutyl, N-phenyl ethyl and cyclic amines [piperidinyl (piperidide), 2,3-dehydro-piperidinyl (piperideide), pyrrolidinyl and pyrrolidyl]. In addition to this, residues of other minor amides including N-4methylbutyl, N-tyramidyl and O-methyl-tyramidyl have also been found (Gregor, 1984). This study corroborate with the above report with respect to few of the acetylenic acid residue alkamides identified in the present study in species of Spilanthes.

All purely olefinic amide structures reported in Heliantheae contain either a $C_{10}$ or $C_{12}$ olefinic chain, with two exceptions: one was in Acmella (Spilanthes) ciliata with two octadien (isobutyl and phenylethyl) amides (Martin and Becker, 1984).The present study is in agreement with the above on isobutyl amide. These amides have even number of carbon atoms. But in contrast, the acetylenic amides in the same tribe contain a wide range of the olefinic chains from $C_{9}$ to $C_{18}$, including both even and odd number of carbons (Christensen and Lam, 1991). Species of Spilanthes from peninsular India have both even and odd numbered carbon amides (Table 4).

Table 4: Alkamides identified in species of Spilanthes

\begin{tabular}{|c|c|c|c|c|}
\hline \multirow[t]{2}{*}{ R.T. } & \multirow{2}{*}{$\begin{array}{l}\text { Species and alkamides } \\
\text { Spilanthes calva }\end{array}$} & \multicolumn{3}{|c|}{ Quantity ( in percentage ) } \\
\hline & & Leaf & Inflorescence & oot \\
\hline 48.09 & $\mathrm{~N}$ isobutyl $2 \mathrm{E}, 4 \mathrm{Z}, 8 \mathrm{Z}, 10 \mathrm{E}$ dodecatetraenamide & 0.6082 & 3.8010 & 0.6599 \\
\hline 49.804 & $\mathrm{~N}$ (methylbutyl ) undeca $(2 \mathrm{E}, 4 \mathrm{Z}$ ) diene 8,10 diyamide & 0.0816 & 0.6898 & 0.1491 \\
\hline \multirow[t]{2}{*}{51.032} & $\mathrm{~N}(2$ methyl butyl) $2 \mathrm{E}, 4 \mathrm{E}, 8 \mathrm{Z}, 10 \mathrm{E}$ dodecatetraenamide & 0.4826 & 0.4567 & 0.1177 \\
\hline & Spilanthes ciliata & & & \\
\hline \multirow[t]{2}{*}{48.472} & $\mathrm{~N}$ isobutyl 2E 4Z 8Z 10E Dodecatetraenanmide & 0.4179 & 0.3645 & 0.6235 \\
\hline & Spilanthes oleracea & & & \\
\hline 41.164 & $\mathrm{~N}$ isobutyl $2 \mathrm{E}, 6 \mathrm{Z} 8 \mathrm{E}$ decatrienamide & 8.5062 & 9.2704 & $*$ \\
\hline 42.042 & $\mathrm{~N}$ isobutyl $2 \mathrm{E}, 6 \mathrm{Z} 8 \mathrm{E}$ decatrienamide & 0.2618 & 5.4793 & 0.2483 \\
\hline 48.404 & $\mathrm{~N}$ isobutyl 2E 4Z 8Z 10E Dodecatetraenamide & $*$ & 0.1200 & 0.1698 \\
\hline 39.714 & N-Isobutyl-(6Z,8E)-decadienamide & 0.0424 & 0.6839 & 0.0393 \\
\hline 50.537 & N 2 methyl butyl 2E 4E $8 Z 10$ E dodeca tetraenamide & $*$ & $*$ & 0.6887 \\
\hline 51.222 & N-(2-Phenylethyl)-cis-2,3-epoxynona-6,8-diynamide & 0.0190 & 0.0704 & 0.0572 \\
\hline \multirow[t]{2}{*}{52.986} & NN (2 phenyl ethyl 2E 6Z 8E decatrienamide) & 0.4071 & 2.6949 & 0.0220 \\
\hline & Spilanthes radicans & & & \\
\hline 47.51 & $\mathrm{~N}$-(2-Phenylethyl)(2Z,4E)-octadienamide & 1.1362 & $*$ & $*$ \\
\hline 49.8 & (2E)-N-(3-Ethynylphenyl)-3-phenyl-2-propenamide & 0.3411 & $*$ & $*$ \\
\hline
\end{tabular}




\begin{tabular}{|c|c|c|c|c|}
\hline & Spilanthes uliginosa & & & \\
\hline 41.182 & $\mathrm{~N}$ - isobutyl 2e, $6 \mathrm{Z} 8 \mathrm{E}$ deca trienamide & 0.4065 & * & 0.4097 \\
\hline 42.213 & $\mathrm{E}, \mathrm{E}, 10,12$ Hexadecadienal & $*$ & 0.5547 & $*$ \\
\hline 48.111 & $\mathrm{~N}$ - isobutyl 2E, 4Z, 8Z, $10 \mathrm{E}$ dodecatetraenamide & 1.7814 & $*$ & 3.8096 \\
\hline 48.659 & $\mathrm{~N}$ - isobutyl 2E, 4Z, $8 \mathrm{Z}, 10 \mathrm{E}$ dodecatetraenamide & * & * & 2.8019 \\
\hline 50.497 & $\begin{array}{l}\mathrm{N}(2 \text { methyl butyl) undeca }(2 \mathrm{E}, 4 \mathrm{E}, 8 \mathrm{Z}, 10 \mathrm{E}) \\
\text { dodecatetraenamide }\end{array}$ & * & * & 0.5922 \\
\hline 51.834 & $\mathrm{~N}(2$ methyl butyl) undeca $(2 \mathrm{E}, 4 \mathrm{Z})$ diene & 0.6246 & 0.9027 & $*$ \\
\hline
\end{tabular}

Plant parts used: Leaf, inflorescence and root.

Very few documents are available for differentiating species of Spilanthes based on chemical variation. The chemical compounds have been isolated, identified and quantified for medicinal purposes. In addition to morphology, revision of the tribe Heliantheae was also based on few chemical components with chemotaxonomic significance (Herout 1971; Stuessy 1977). The evaluation of evolutionary relationship in Asteraceae could not be confirmed only on the basis of morphological characters. The status of Spilanthes was revised and transferred from Verbesininae tribe to Galinsoginae and then to individual tribe Spilanthinae (Robinson 1932; Stuessy 1977; Panero and Funk 2002). Based on the morphological characters, Spilanthes genus was further divided into Spilanthes and Acmella, sub-sections (Moore 1907; Cassini 1836). Recent studies on morphology and chromosomes supported the generic status of Spilanthes and Acmella individually (Jansen 1981; 1985). The present study provides information on chemical composition of the species of Spilanthes present in peninsular India, however there have been no reports of detailed chemical studies after the revision of Spilanthes (Jansen 1981; 1985). Hence, the chemical profiling of both the genera Acmella as well as Spilanthes are crucial for the confirmation of the genus status in addition to morphological markers. However, standard Acmella specimens were neither been identified nor are they found as herbaria specimens.

Whenever the morphological characters are not sufficient for identification as in case of separation of S. paniculata that possessed rayed heads (in India) as well as discoid heads (Jansen, 1981), chemical markers could be employed in support of the chemotaxonomic classification of species.

\section{CONCLUSION}

The present study figures the groundwork for the chemical investigation of species of Spilanthes distributed in peninsular India. This is the first report of profiling of chemical compounds in six species by GCMS-MS. As most of the species of Spilanthes are distributed throughout the world with medicinal properties, a detailed study of chemical components is necessary for authentication of species as well as the systematic position of the genus and their applications in modern medicines.

\section{ACKNOWLEDGEMENT}

The authors wish to thank The Director, Indian Institute of Horticultural Research, Bangalore for providing facilities to conduct the research work. We are thankful to Dr. K.S. Shivashankara and Dr. S. Shivashankar for Lab Facility and valuable suggestions and Mr. Tapan Kumar Roy and Mr. Bujji Babu for technical support for the present study.

\section{REFERENCES}

1. Anon, 2013. Sesquiterpenes and alkamides from Spilanthes americana M.Sc. dissertation.

2. Bae SS, Ehrmann BM, Ettefagh KA Cech NB (2010). A validated liquid chromatography-electrospray ionization-mass spectrometry method for quantification of spilanthol in Spilanthes acmella (L.) Murr. Phytochem Anal. 5: 438-443.

3. Baruah RN, Pathak MG (1999). Hydrocarbons from the flower heads of Spilanthes acmella. Journal of Medicinal and aromatic Plant Sciences 3: 675.

4. Begum J, Bhuiyan MNI, Chowdhury JU (2008). Essential oil from inflorescence of Spilanthes calva D.C. Bangladesh Journal of Botany.37(2): 217-218. 
5. Boonen J, Baert B, Burvenich C, Blondeel P, De Saeger $\mathrm{S}$, De Spiegeleer B (2008). LC-MS profiling of Nalkylamides in Spilanthes acmella extract and the transmucosal behaviour of its main bio-active spilanthol. Journal of Pharmaceutical and Biomedical Analysis. J Pharm Biomed Anal. 53(3): 243-9

6. Cassini H (1822). Spilanthes: In Dictionaries des sciences naturelles, by $\mathrm{H}$. Cassini, Paris: Le Normant. 24: 328- 331.

7. Chakraborthy BRK, Devvi R, Sanjebam, Khumbog S, Thackom S (2010). Preliminary studies on local anesthetic and antipyretc activities of Spilanthes acmella Murr. in experimental animal models. Indian J Pharmacol. 42(5):277-9

8. Christensen LP, Lam J (1991a). Acetylenes and related compounds in Heliantheae. Phytochemistry. 30: 11-49.

9. Christensen LP, Lam J (1991b). Acetylenes and related compounds in Asteraceae (= Compositae). 3. Acetylenes and related compounds in Astereae. Phytochemistry. 30:2453-2476

10. Christophe W (2006). Ethnopharmacology of Medicinal Plants. Asia and the Pacific Humana Press, Totowa, NJ, USA.

11. Chung KF, Yoshiko K, Wang CM, Peng C (2008). Notes on Acmella (Asteraceae: Heliantheae) in Taiwan. Botanical Studies. 49:73-82.

12. Greger H (1984). Alkamides Structural relationships distribution and biological activity. Planta Medica. 50: 366-375.

13. Herout V (1971). Chemotaxonomy of the family Compositae (Asteraceae). In H. Wagner y L Horhammer (eds.), Pharmacognosy and Phytochemistry. 93-111.

14. Jansen RK (1981). Systematics of Spilanthes (Compositae : Heliantheae). Syst. Bot. 6: 231 - 257.

15. Jansen RK (1985). The systematics of Acmella (Asteraceae - Heliantheae). Syst. Bot. Monogr., 8:1-115.

16. Joelma AM, Paula A, Pedro H, Ferri B, Maria TF, Bara C, Leonice MF, Tresvenzol C, Fabyola AS, Sác JR, Paula C (2011). Infraspecific chemical variability in the essential oils of Pimenta pseudocaryophyllus (Gomes) L.R. Landrum (Myrtaceae). Biochemical Systematics and Ecology. 39: 643-650.

17. Jondiko IJO (1986). A mosquito larvicide in Spilanthes mauritiana. Phytochemistry. 25(10): 2289-2290.

18. Jones SB, Luchsinger AE (1986). Pteridophyta, Plant Systematics, 2ndedn. McGraw-Hill Book Company, p. 261.

19. Leng TC, Ping NS, Lim BP, Keng CL (2011). Detection of bioactive compounds from Spilanthes acmella (L.) plants and its various in vitro culture products. Journal of Medicinal Plants Research. 5(3):371-378.
20. Manilal KS, Sivarajan VV (1982). Flora of Calicut. Bishen Sigh Mahendra Pal Sigh, Dehra Dun. 153-154.

21. Martin R, Becker H (1984). Spilanthol- related amides form Acmella ciliata. Phytochemistry. 23:1781-1783.

22. Moore AH (1907). Revision of the genus Spilanthes. Proceedings of the American Academy of Arts and Letters. 42: 521.

23. Nakatani N, Nagasimha M (1992). Pungent alkamides for Spilanthes oleracea L. var. Clarke. Biosci. Biotech. Biochem. 56: 759-762.

24. Pandey V, Agarwal V (2009). Efficient micropropagation protocol of Spilanthes acmella L. possessing strong antimalarial activity. In vitro Cell. Dev. Biol. Plant. 45: 491-499.

25. Pandey V, Chopra M, Agrawal V (2011). In vitro isolation and characterization of biolarvicidal Compounds from micropropagated plants of Spilanthes acmella. Parasitol Res. 108: 297-304.

26. Panero JL, Funk VA (2002). Toward a phylogenetic subfamilial classification for the Compositae (Asteraceae). Proceedings of the Biological Society of Washington. 115: 909-922.

27. Phrutivorapongkul A, Suwanna AC, Netisingha VW, Chansakaow S (2008). An Anesthetic Alkamide And Fixed Oil From Acmella Oleracea. J. Health Res., 22(2): 97-99.

28. Prachayasittikul S, Suphapong S, Worachartcheewan A, Lawung R, Ruchirawat S, Prachayasittikul V (2009). Bioactive metabolites from Spilanthes acmella Murr. Molecules. 14(2): 850-867.

29. Pullaiah T, Moulali DA (1997). Flora of Andhra Pradesh (India). Scientific Publishers, Jodhpur, India. 2: 538.

30. Rajesh Y, Kharya MD, Yadav N, Savadi R (2011). Diuretic activity of Spilanthes acmella, Murr. Leaves extract in rats. International Journal of Research in Pharmacy and Chemistry. 1: 57-61.

31. Rajnarayana K, Reddy MS, Chaluvadi MR, Krishna DR (2001). Bioflavonoids classification, pharmacological, biochemical effects and therapeutic potential. Indian J. Pharmacol. 33: 2-16.

32. Ramırez-Chavez E, Lo'pez-Bucio J, Herrera-Estrella L, Molina-Torres J (2004). Alkamides Isolated from Plants Promote Growth and Alter Root Development in Arabidopsis. Plant Physiology. 134: 1-11.

33. Ramsewak RS, Erickson AJ, Nair MG (1999). Bioactive $\mathrm{N}$-isobutylamides from the flower buds of Spilanthes acmella. Phytochemistry. 51(6):729-32.

34. Robinson H (1932). A Revision of the Tribal and Subtribal Limits of the Heliantheae (Asteraceae).

35. Saldanha CJ, Nicholson DH (1976). The Flora of Hassan District, Karnataka. Amerind Publishing Co. Pvt. Ltd., New Delhi: 623- 624. 
36. Savadi R, Yadav R, Yadav N (2010). Study on immunomodulatory activity of ethanolic extract Spilanthes acmella Murr. Leaves. Indian J. Nat. Prod. Res. 1: 204-207.

37. Shanthi P, Amudha P (2010). Evaluation of the phytochemical constituents of Acmella calva (DC.) R.K. Jansen. International Journal of Pharma and Bio Sciences, 1(4): 3-6.

38. Standley PC, Calderon S 1944. Lista Preliminar de las Plantas de El Savador.

39. Stuessy TF (1977). Heliantheae-Systematic Review. In: The biology and Chemistry of the Compositae (Heywood, V.H., Harbone, B. and Turner, L. eds.), Academic Press, London.
40. Swamy KNR, Prasanna S, Seshadri TR Vedhanth TNC (1975). $\alpha \& \beta$ amyrin esters and sitosterols glycoside from Spilanthes acmella. Phytochemistry. 14(7): 16661667.

41. Timothy M, Crafter SA (1982). Wetlands Ecology and Priorities for Conservation in Zimbabwe. Proceedings of a seminar on wetlands in Zimbabve. 76.

42. Trease GE, Evans WC (1972). Phenolic compounds and tannins, Pharmacognosy. $4^{\text {th }}$ ed., Bailliere Trindall, London. 146-148.

43. Wahab OM, Ajala OO, Ojo MO, Egunjobi AJ (2013). Ethnomedicinal and Phytochemical profile of Spilanthes filicaulis (Schum \& Thonn) CD Adams (Astaraceae) in Ibadan metropolis. Heal. Herbs Pract Technol. 2:13-18.
* Corresponding Author: Lavanya Devi K*

Email: lavanyakotekar@gmail.com 